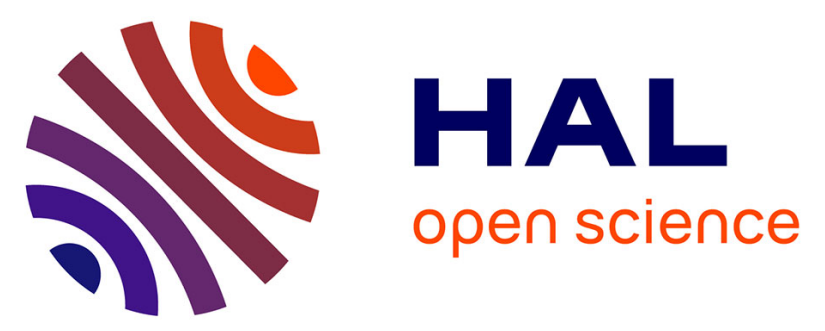

\title{
Essay Review: Hilary Marland. Dangerous Motherhood: Insanity and Childbirth in Victorian Britain. Basingstoke and New York: Palgrave Macmillan, 2004. Pp. xii + 304. £52.50. ISBN 1403920389 \\ Margaret L. Arnot
}

\section{To cite this version:}

Margaret L. Arnot. Essay Review: Hilary Marland. Dangerous Motherhood: Insanity and Childbirth in Victorian Britain. Basingstoke and New York: Palgrave Macmillan, 2004. Pp. xii + 304. £52.50. ISBN 1403920389. History of Psychiatry, 2007, 18 (4), pp.503-510. 10.1177/0957154X07083424 . hal-00570912

\section{HAL Id: hal-00570912 \\ https://hal.science/hal-00570912}

Submitted on 1 Mar 2011

HAL is a multi-disciplinary open access archive for the deposit and dissemination of scientific research documents, whether they are published or not. The documents may come from teaching and research institutions in France or abroad, or from public or private research centers.
L'archive ouverte pluridisciplinaire HAL, est destinée au dépôt et à la diffusion de documents scientifiques de niveau recherche, publiés ou non, émanant des établissements d'enseignement et de recherche français ou étrangers, des laboratoires publics ou privés. 


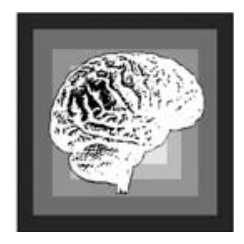

\title{
Essay Review
}

\author{
MARGARET L. ARNOT* \\ Roehampton University, UK
}

\section{Hilary Marland. Dangerous Motherhood: Insanity and Childbirth in Victorian Britain. Basingstoke and New York: Palgrave Macmillan, 2004. Pp.xii + 304. £52.50. ISBN 1403920389.}

At last readers of History of Psychiatry have a published monograph about puerperal insanity. ${ }^{1}$ Adopting a social constructionist approach, Marland effectively reveals the social, physiological and contextual causality of this nineteenth-century condition, yet manages to convey how it remained 'an untidy, elusive disorder' (p. 178) without any shared understanding of a unique symptomology, or treatment protocol. The author conveys a world more humane than perceived by historians emphasizing the 'social control' function of asylums and more nuanced than that seen by earlier feminist scholars. The argument about the condition's particular temporal location is mainly convincing, although its demise as a disease category was probably less neat than the author proposes: it remained useful as a defence in infanticide trials and remained within the lexicon of some obstetricians and psychiatrists into the early decades of the twentieth century (Grey, forthcoming). Puerperal insanity was the terrifying antithesis of the maternal ideal so central to the development of bourgeois domestic values in this period; and early nineteenth-century constructions of women as sickly and fragile provided the broader medical context for the making of this disease.

Although focusing mainly on the historical specificities of this condition, Marland also suggests continuities in human bodily and mental experience. Since Hippocrates there has been an awareness that pregnancy and labour could disturb the mental equanimity of women. In Dangerous Motherhood we gain glimpses of childbed madness from Margery Kempe's medieval torment: 'She would have killed herself many a time as [the devils] stirred her to ...' (p. 9), to Andrea Yates in twenty-first century Texas who claimed

* Address for correspondence: School of Arts, Digby Stuart College, Roehampton University, Roehampton Lane, London SW15 5PH, UK. Email: M.Arnot@roehampton.ac.uk 
that her five children whom she drowned 'stumbled because I was evil' (pp. 204-5). The religious framework essential to understanding the conditions in Kempe's time no longer influenced nineteenth-century medical explanations, although the patient's view could still include religious language. General fear of childbirth remains to this day, yet also had a particular role to play in the nineteenth-century context. The reader is probably left with more questions about such continuities than explanations, yet to finish reading with curiosity stimulated is the result of the best history books.

What is most historiographically original is Marland's challenge to feminist scholarship. Identifying herself with those who have 'nuanced and revised' (p. 142) both Elaine Showalter's and Mary Poovey's views, Marland accepts that women asylum patients became more visible during the nineteenth century, yet disagrees with Showalter's claim that it was constructions of proper feminine behaviour that explained increasing numbers of female asylum patients. There were more complex social and demographic factors, including variations between institutional practices, higher mortality of male inmates, and women's economic dependence that made them more vulnerable to institutionalization. Women were incarcerated in a proportion appropriate to their numbers in the population at large, and gender did not play a dominant role in diagnosis in asylums (Wright, 2004). The will and determination evident in Sara Coleridge's diary is used by Marland to question Showalter's characterization of mental affliction as an 'unconscious form of feminist protest' (p. 91). The author also suggests that medical explanations of women's insanity and doctor-patient relationships did not rest almost exclusively on women's reproductive biology as claimed by Showalter and Poovey. However, Marland acknowledges some accuracy in feminist views, suggesting that these doctors legitimized and strengthened notions that women were physically frail and consequently more susceptible to mental illness. As regards class, far from agreeing with Jane Ussher that working-class women were too busy to be 'mad', Marland discovered many poor women in the harrowing case records of the Edinburgh and Warwickshire asylums, and a recognition among physicians that their poverty could have contributed to their loss of reason. Marland suggests that the diagnosis could have been positive for the women themselves, 'opening up the possibility of respite from household and maternal duties' (p. 142). Women who remained in asylums until their deaths may have found a life with more comfort, security and better nutrition than any other option. It is hard to imagine a more damning indictment of a society's gendered power structures than this.

Readers of History of Psychiatry will be interested in the status of the disease as an ambiguous category 'in terms of knowledge and treatment' (p. 35). Throughout the book, the different claims and approaches of midwifery practitioners and alienists are explored. They all agreed that the disease existed in two forms: mania and melancholia - the former most alarming, the latter most intransigent. Citing widely variant statistical data, Marland 
concludes that it is impossible to determine how many women suffered from the condition, or whether it was most frequently treated at home or in the asylum. The disease could be 'hidden' by domestic treatment and by different diagnostic practices in asylums. Certainly, medical attention to puerperal insanity contributed to the perception that it was increasing. While a few eighteenth-century midwifery practitioners and alienists mentioned childbed madness, it was early nineteenth-century male midwives who first paid it serious attention. By mid-century it was standard fare in textbooks on women's disorders, and widely known among practitioners. It followed a similar trajectory from specialized writings earlier in the century, into textbooks of psychological medicine by mid-century. Marland suggests that there were preconditions for the invention of the diagnosis. Reproduction was seen as a risky business after the death of Princess Charlotte in childbirth in 1817, encouraging greater medical intervention into childbirth. Traditional female support networks were increasingly excluded from the lying-in room, creating isolation and intensifying fear associated with childbirth, which medical men then sought to pacify by expert guidance. The rise of male midwifery and obstetrics, psychiatry, lying-in hospitals and asylums provided the 'experts' and the professional settings for the accumulation of experience. There were different emphases in aetiological explanations, which Marland suggests was at least partly caused by the two different kinds of specialists having patients from different social groups. Midwifery practitioners emphasized the strain of reproductive processes, while alienists highlighted environmental and circumstantial factors learnt through their pauper asylum patients, although all practitioners included references to environmental and social causes in their case notes. Experts from both fields agreed on the importance of both physical therapy and moral management in treating patients, but differed regarding the best place for that to occur. Midwifery practitioners tried to keep patients at home, whereas alienists became increasingly convinced that the re-establishment of propriety and self-control was best facilitated in the asylum.

Through the work of Allan Beveridge in particular, regular readers of History of Psychiatry will be familiar with the rich case notes and letters in the Royal Edinburgh Asylum records. It is Hilary Marland's novel use of such sources to explore a particular psychiatric condition, together with the inclusion of case studies, that give the book its particular power. Four brief, contrasting case studies ranging from Queen Victoria to a rural Welsh mother of an illegitimate child draw the reader in at the beginning. Puerperal insanity in wealthy homes is presented in a vivid way in Chapter 3, especially through case studies of Isabella Thackeray and Sara Coleridge. While there is nothing to compare with Sara Coleridge's diary for working-class sufferers, the asylum case notes used by Marland for Chapters 4 and 5 provide accounts almost as intimate. 
The main theme of the chapter about Thackeray and Coleridge is domestic disorder presented as both cause and result of puerperal insanity. The physician's role in such cases was not only to cure the patient, but also to restore order to the household and to prevent any recurrence. Removal of a patient to an asylum severed household bonds and signalled the practitioner's failure in this mission. At its worst, this became a domestic tragedy, with children and mothers separated long-term, sometimes for life, which was the fate of Isabella Thackeray, 'dead to us all' (p. 85) according to William Makepeace Thackeray. Sara Coleridge was intermittently separated from her household, often leaving its management to her mother and servant. The reader is taken into the homes, parlours and bedrooms of the affected well-to-do families, and to private asylums and other therapeutic places in Britain and Europe. Marland writes about sufferers, some family members and practitioners with keen observation and compassion. We read of Sara Coleridge's mental sufferings, her physical ailments, the state of her bowels, including her own eloquent descriptions of melancholic states, as she struggled with puerperal melancholia between 1832 and 1843. At the same time a woman emerges who negotiated her way through a minefield of mental anguish with a will mostly intact, and determined to control who her medical advisors were, to adhere to whichever advice she chose, and to hew out space to read and write.

Chapter 4 takes the reader into the 'galleries' of the Royal Edinburgh Asylum. The patients' behaviour is vividly described: ranting, tearing their clothes, defecating inconveniently, seducing doctors, masturbating, repeatedly reciting scripture, refusing food or communication, self-harming, attempting suicide, destroying asylum property and assaulting other inmates. Medical literature discussing symptoms is analysed, and we sense the doctors' satisfaction that many of these women were successfully restored to their families. Marland's historical argument about their perceived difference from other psychiatric patients would have been strengthened by comparing the case notes of women classified as suffering with puerperal ailments with those of patients classified differently. That said, both patient experience and doctors' perceptions are presented here with immediacy. With a clearly-recorded diagnosis written at the top of each patient's entry (in these cases, 'puerperal mania', 'puerperal melancholia', 'insanity of pregnancy' or 'lactational insanity'), the case notes reflected David Skae's (1814-73) classification system based on the relationship between physiological and psychological states (Skae, 1863, 1873, 1874). Understandings of aetiology and treatment regimes outlined in the case histories bring to life an holistic mid-century understanding of mental affliction that saw body and mind as integrally related, and impacted by both moral considerations and environmental factors such as poverty, poor nutrition and domestic strife and disorder. Therapeutic regimes focusing on both physical and moral treatments can be rationally linked to this aetiology, yet what also emerges is a pragmatic, empirical practice that responded to immediate need and explored various alternatives until something worked. 
Most patients received mild treatments comprised of a good diet, rest, purges to ensure bowel regularity and, above all, moral therapy such as occupation 'through work, exercise and rational pursuits' (p. 99), and the re-instilling of ordered diurnal rhythms and a self-controlled demeanour. Yet at an individual level, particularly malnourished (or food-refusing) patients could be force-fed, and refractory patients could be subjected to the trials of 'heroic medicine': blistering, powerful medicines that could include both stimulants, opiates, other anodynes and ointments, cold baths, and being placed in isolation. The number of patient 'escapes' mentioned in passing is silent testimony to some patients' intolerance of such treatment, though another story has a patient returning after release saying she preferred it at the asylum. Although Marland notes a surprising lack of moral censure in the case notes, the influence of physiognomy and phrenology could lead to cruel judgements: 'few patients excited the vehemence of Jane Stirling, with her "ill-shaped head" reflecting her intrinsically, irredeemably bad character' (p. 113). I was left wondering why Marland did not undertake some basic statistical analysis of her cases to compare with the data she presents collected by John B. Tuke (1835-1913) when he was Assistant Physician at the asylum between 1864 and 1865. Some simple use of descriptive statistical tables or charts would have helped to elucidate much of the information presented in the chapter, yet if any reader still needs to be convinced of the value of case notes as sources, this chapter will do the trick.

In Chapters 5 and 6 Marland argues that the most important element beyond women's perceived biological fragility affecting understandings and treatment of puerperal insanity was motherhood and family problems. Doctors recognized that motherhood could be very difficult, and families were frequently the butt of medical criticism. As well as providing woefully inadequate care, families could mislead doctors, and could disrupt households and patients enough to cause insanity in the first place, and then prevent recovery from it. Removal from family influences was considered crucial. Husbands specifically were very often seen as beyond the pale, 'an outright danger' to their wives' sanity (p. 161). The doctors' condemnation was mirrored by the women's hatred of their husbands; Dr Robert Boyd of Somerset County Lunatic Asylum believed this to be as much a characteristic of the disease as women's hatred of their babies. This medical criticism of family relationships had something in common with Frances Power Cobbe's campaign on behalf of women needing to escape marriages, and perhaps more could have been made of this intriguing possibility that feminists and medical men had some ground in common. It would be very interesting to consider how the critique of husbands relates to contradictions within the domestic expectations of men in the nineteenth century - something that would strengthen the gender analysis of the book (Davidoff, Doolittle, Fink and Holden, 1999; Wiener, 2004). Husbands were not the only hazard to child-bearing women. Alienists considered that the long periods of 
breast-feeding common for working-class women made them more vulnerable to puerperal insanity, as did poverty, malnutrition, physical exhaustion, and the demands of rearing large families. For wealthier women, physical luxury and lack of preparation for childbearing were blamed, too, while they shared with poorer women vulnerability to lactational insanity if they breastfed too long. Bearing children out of wedlock was also seen by the majority of doctors as carrying particular risks for puerperal insanity: anxiety caused by poverty, amplified by the fear and sense of disgrace associated with bearing an illegitimate child, were particularly to blame.

Sympathy for unmarried mothers suffering from puerperal insanity accords with the frequent lenience of the courts in the nineteenth century when dealing with mothers who were accused of killing their own newborn infants. The author has been able to link the court records of some infanticide cases with asylum admissions in Warwick. The varied views of infanticidal women within the asylum - immune to or distressed by their crime, treated generally with compassion, some being successfully returned cured to their families, some returning to the asylum again and again - all this makes a valuable contribution to the social history of infanticide. Marland also adds to our understanding of the ways in which lay, medical and legal views contributed to the outcome of insanity defences in the nineteenth century (Eigen, 2005). Puerperal insanity became increasingly available as a defence (it moved into forensic texts mid-century) at about the same time as the midVictorian 'infanticide panic' created a yawning gap between some areas of public opinion, horrified by the alleged levels of infanticide, and the continuing lenient practices of the courts. The defence served as mediation between these two positions and provided a seemingly 'scientific' explanation for behaviour previously seen as just senseless. Despite the infanticide panic, all concerned (neighbours, witnesses, judges, jurors, medical men, laymen) seemed keen to embrace the label of insanity that meant these women escaped conviction for murder, but also enabled retribution of a different kind. Infanticide was the very worst possible outcome of a mental affliction that threatened unpredictable violence. Puerperal insanity itself was seen as a risk for all parturient women, because the trauma of child-bearing was considered to be a key cause: all this leads to the argument that 'infanticide ... was not seen as the antithesis of but as an intrinsic part of motherhood' (p. 200). The argument that at this time all working-class women were seen to be capable of committing infanticide by neglect has already been made (Arnot, 1994), but Marland's book increases understanding of the implications of nineteenth-century views of women's constitutions. If no woman was strong enough to be capable of motherhood without the risk of insanity and infanticide, women's greatest strength, and a fundamental plank of feminist calls for greater political acknowledgement, was undermined. Insanity and infanticide were certainly not attributes to be drawn on in any positive way in the public domain, and all the more reason for both medicine 
and developing state institutions to invent the notion that women needed expert guidance in mothering. It is a pity that Marland did not explore these broader implications of her argument.

In her final chapter Marland's critique of the disappearance of the diagnosis with the rise of Kraepelian diagnostic categories is informed by a gender politics that seeks the best treatment for individual sufferers. Marland considers twentieth-century therapeutic regimes to be harsher, and cites the recent Texas case of Andrea Yates as evidence of much less sympathetic treatment in the judicial process when the insanity defence is raised in infanticide trials, though reference to recent British cases would have been of more relevance to this book. In contrast, nineteenth-century alienists emerge as dedicated men striving to do the best for their patients, and the asylums as places of refuge where women were administered treatments that were usually gentle, were given time to heal, and where recovery rates were good.

Dangerous Motherhood will make valuable reading for historians of medicine and psychiatry and for scholars in gender studies. The combination of accessibility with excellent scholarship ensures its appropriateness for both undergraduate and postgraduate courses. Elegance is at times a little compromised in favour of stylistic clarity, but that is a small gripe about an excellent book. More annoying are: a few minor bibliographical inaccuracies that should have been avoided; and the fact that statistical data referred to in discussion are not always in commensurate form, making comparisons difficult. The book is rich in evocative descriptive material, but at times analysis could have been deepened.

Dangerous Motherhood contributes to many areas of understanding; ideologies of domesticity, femininity and maternity; the medicalization of women; relationships between doctors, patients and their families; medical practitioners' ambitions to establish their reputations and practices, and their concerns to cure patients and relieve families of the burdens of puerperal insanity; and ideas of female madness among the wealthy and poor in the Victorian period. Every reader of this journal should be very well rewarded by reading this book.

\section{Note}

1. Studies remaining in dissertation form: Day, 1986; Nakamura, 1999; Quinn, 2003.

\section{References}

Arnot, M. L. (1994) Infant death, child care and the state: the baby-farming scandal and the first infant life protection legislation of 1872. Continuity and Change, 9, 271-311.

Davidoff, L., Doolittle, M., Fink J. and Holden, K. (1999) The Family Story (London and New York: Longman).

Day, S. (1986) Puerperal insanity: the historical sociology of a disease. Unpublished $\mathrm{PhD}$ thesis, University of Cambridge. 
Eigen, J. P. (1995) Witnessing Insanity (New Haven and London:Yale University Press).

Grey, D. (forthcoming) Representations of infanticide in England 1880-1922. Unpublished $\mathrm{PhD}$ thesis, Roehampton University.

Nakamura, L. E. (1999) Puerperal insanity: women, psychiatry, and the asylum in Victorian England, 1820-1895. Unpublished PhD thesis, University of Washington.

Quinn, C. L. (2003) Include the mother and exlude the lunatic: a social history of puerperal insanity, c. 1860-1922. Unpublished PhD thesis, University of Exeter.

Skae, D. (1863) A rational and practical classification of insanity. Fournal of Mental Science, 9, 309-19.

Skae, D. (1873, 1874) The Morisonian Lectures on Insanity for 1873. Fournal of Mental Science, 19, 340-55; 20 (1874), 1-20.

Smith, R. (1981) Trial by Medicine (Edinburgh: Edinburgh University Press).

Tosh, J. (1999) A Man's Place (New Haven and London: Yale University Press).

Wiener, M. (2004) Men of Blood (Cambridge: Cambridge University Press).

Wright, D. (2004) Delusions of gender? Lay identification and clinical diagnosis of insanity in Victorian England. In J. Andrews and A. Digby (eds), Sex and Seclusion, Class and Custody: Perspectives on Gender and Class in the History of British and Irish Psychiatry (Amsterdam \& New York: Rodopi), 149-76.

\section{Acknowledgements}

The editor would like to thank the Members of the Advisory Board, the assistant editors and the many colleagues for their sterling help with the onerous task of refereeing the papers submitted to History of Psychiatry. It would be difficult to run the journal without their generous support.

Thanks are also due to the Book Review Editors whose industry and perseverance maintain one of the important sections of our Journal. 